\title{
THE «AFGHAN QUESTION» AT THE SIXTH EMERGENCY SPECIAL SESSION OF THE UNITED NATIONS GENERAL ASSEMBLY (10-14 JANUARY 1980)
}

\begin{abstract}
Introduction. Soviet invasion to the Democratic Republic of Afghanistan in December 1979 and continued participation of the USSR in the Afghan crisis became the most high-profile event of international life of 1970 - 80-th. The world community perceived Soviet intervention as a significant threat to international peace and security. The Sixth emergency special session of the United Nations General Assembly was held to consider the situation in Afghanistan.

The purpose of the article is to investigate the discussion of the "Afghan issue» at the Sixth emergency special session of the United Nations General Assembly 10 - 14 january 1980 and to analyze the impact of the "Afghan issue» on the system of international relations during the Cold War.

Results. The Security Council met from 5 to 9 January 1980 to consider the situation in Afghanistan and its implications for international peace and security.

A draft resolution calling for the immediate, unconditional and total withdrawal of the foreign troops was vetoed by the Soviets on 7 January. Two days later the Security Council adopted Resolution 462 acknowledging the lack of unanimity of its permanent members was preventing them from fulfilling their primary duty of maintaining peace and security, invoking the General Assembly's "Uniting for Peace» resolution calling for an emergency special session. This was adopted with 12 supports, 2 opposes (USSR and German Democratic Republic), with 1 abstention (Zambia).

At the Sixth emergency special session was dominated by questions of its legitimacy. Afghanistan and the Soviet Union denounced the meeting as interfering with domestic affairs of a Member State and that they were exercising their Treaty of Friendship and their right to collective self-defense under Article 51 of the UN Charter. Most of the delegations rejected the arguments of the Soviet and Afghan sides. 108 countries condemned the Soviet aggression on January, 14 (18 countries abstained, the same number supported the USSR).
\end{abstract}

Conclusion. The General Assembly adopted Resolution ES-6/2 strongly deploring the recent armed intervention in Afghanistan and calls for the immediate, unconditional and total withdrawal of the foreign troops from Afghanistan. However, the decisions of the General Assembly were recommendatory. In addition, the consideration of the "Afghan issue » at the United Nations has shown the lack of a mechanism for influencing an aggressor country that has a veto power in the UN Security Council. These events also marked the transition to a new phase of the Cold War in international relations.

Key words: General Assembly of the United Nations; Soviet invasion; The Democratic Republic of Afghanistan; Cold War.

Одержано редакцією 12.10 .2020

Прийнято до публікації 6.11.2020

\author{
УДК 719:008-048.42(474.5) \\ DOI: 10.31651/2076-5908-2020-2-120-127
}

\section{ХАРКОВЕНКО Роман \\ Володимирович,}

кандидат історичних наук, головний

спеціаліст Міністерства культури

та інформаційної політики України, e-mail: kredo3@ukr.net

Orcid ID: 0000-0002-3447-1391

\section{МІЖНАРОДНИЙ АСПЕКТ ОХОРОНИ ПАМ'ЯТОК КУЛЬТУРНОЇ СПАДЩИНИ РЕСПУБЛІКИ ЛИТВА}

У статті аналізуються міжнародні особливості охорони пам'яток культурної спадщини Республіки Литва. Здійснено огляд пам'яткоохоронного законодавства і принщипів державного управління вказаної республіки. Виокремлено начіональні особливості виявлення, досліджсення, обліку, охорони, збереження й використання пам'яток культурної спадщини у Республіиі Литва.

Ключові слова: охорона культурної спадщини, об'єкт культурної спадщини, пам'ятка, Список всесвітньої спадщини ЮНЕСКО, Міжурядовий комітет з охорони всесвітньої культурної $і$ природної спадщини, Конвенція про охорону культурної і природної спадщиини. 
Постановка проблеми. Кожна країна у світі прагне якомога ефективніше охороняти i зберігати свою культурну спадщину. У законодавствах переважної більшості держав світу пам'ятки культурної спадщини поділяються на три категорії: місцевого, національного та міжнародного (всесвітнього, світового) значення (пам'ятки ЮНЕСКО). Останні за відповідним рішенням вказаної міжнародної організації заносяться до Списку Всесвітньої спадщини ЮНЕСКО (далі - Список).

Скільки держав у світі, стільки ж і практик існує щодо охорони власної культурної спадщини, їі збереження, використання та популяризації, а також співпраці з ЮНЕСКО в зазначеній галузі. На нашу думку, дуже цікавим є досвід з цього питання такої невеликої за територією, але досить свідомої і відповідальної в пам'яткоохоронній царині, країни як Республіка Литва.

Аналіз останніх досліджень і публікацій. Історію законодавства Республіки Литва і практику його застосування в сфері охорони пам'яток культурної спадщини, а також питання виявлення, вивчення, обліку, охорони, збереження, використання, популяризації пам'яток в радянський і пострадянський періоди вивчали такі дослідники як В.І. Акуленко, М.М. Богуславський, Л.Н. Галенська, Й.Р. Глемза, І.П. Магазинщікова, Н.В. Максаківський, В.Р. Крогіус, А.А. Буторін, В.В. Максимов, І.Е. Мартиненко, О. І. Мельничук, Л. В. Павлова, Н. А. Потапова, Е. В. Утко, О.В. Шуміхіна, С.М. Фазлуллін та інші.

Мета. Здійснити аналіз міжнародних особливостей у сфері охорони пам'яток культурної спадщини Республіки Литва.

Виклад основного матеріалу. Культурна спадщина Республіки Литва втілена в пам'ятках, найбільш значущі з яких мають універсальний характер, приймаються під особливу охорону завдяки включенню їх до Списку. На сьогодні до Списку включені наступні об’єкти культурної спадщини, з яких 779 є культурними, 197 природними та 31 змішаними [5, 28]. Конвенцію про охорону культурної і природної спадщини (далі - Конвенція) [2, 66] ратифікували 191 держава, в тому числі і Республіка Литва (31 березня 1992 р.).

Литва гідно представляє свою культурну спадщину у Списку. Розглянемо ці об'єкти:

1. Історичний центр Вільнюса - це один з найбільших у Східній Європі урбаністичних комплексів, які формувалися починаючи з Середніх віків. Займає площу 3,59 кмI, охоплює 74 квартали з 70 вулицями, провулками і будівлями. Важливою особливістю історичної частини Вільнюса є вельми високе збереження цього комплексу, який в порівнянні 3 багатьма іншими містами Східної Свропи значно менше постраждав від воєн та інших потрясінь. Вказаний об'єкт включений до Списку в 1994 р. за критеріями ii, iv (характеристика критеріїв наводиться нижче).

2. Археологічні пам'ятки культурної резервату Кярнаве - можливе місце розташування столиці древніх литовців в сучасному Шірвінтському районі Литви, нині містечко в 35 км на північний захід від Вільнюса. У XIII ст. Кярнаве був великим містом з п'ятьма кріпакамибудівлями. Цей комплексний об'єкт, розташований в долині річки Нярис, включає археологічні залишки стародавнього міста Кярнаве, фортів, кількох неукріплених поселень, а також поховань та інших пам'яток, що відносяться до періоду часу від пізнього палеоліту до середньовіччя. Тут можна спостерігати сліди стародавнього землекористування, а також залишки п’яти стародавніх укріплених городищ, які $є$ частиною потужної оборонної системи. Кярнаве був важливим феодальним містом в Середні віки. I хоча місто було зруйноване в кінці XIV ст. Тевтонським Орденом, це місце було населене протягом ще тривалого часу. Зазначений об'єкт включений до Списку в 2004 p. за критеріями iii, iv.

3. Через Республіку Литва проходить об'єкт всесвітньої культурної спадщини «Дуга Струве». Ця пам'ятка - ланцюг триангуляційних пунктів, що простягнулася на 2820 км по території десяти європейських країн від Хаммерфеста в Норвегії до Чорного моря. Ці опорні точки спостережень були закладені астрономом Фрідріхом Георгом Вільгельмом Струве, який зафіксував, таким чином, перший достовірний вимір великого сегмента дуги земного меридіана. До цього об’єкту увійшли 34 пункти, які марковані на місцевості найрізноманітнішим чином, наприклад: видовбані в скелях поглиблення, залізні хрести, піраміди з каменів або спеціально встановлені обеліски. Вказаний об'єкт включений до Списку в 2005 р. за критеріями ii, iv, vi $[5,28]$. 
Розглянемо, яким чином визначається статус об’ єктів (пам'яток) всесвітньої культурної спадщини в нормативних актах внутрішнього законодавства Республіки Литва і в міжнародних угодах. Здійснивши аналіз механізму міжнародного захисту культурної спадщини, відзначимо наступні особливості правового статусу об'єкта всесвітньої спадщини.

Відповідь на це питання міститься в Конвенції, яка надає поняттю «культурна спадщина» детальну характеристику, класифікуючи його на такі види: пам'ятники, ансамблі, визначні місця $[1,56]$.

Пам'ятники - твори архітектури, монументальної скульптури і живопису, елементи або структури археологічного характеру, написи, печери та групи елементів, які мають видатну універсальну цінність 3 точки зору історії, мистецтва чи науки. Ансамблі - групи ізольованих чи об'єднаних будівель, архітектура, єдність або зв'язок з пейзажем яких є видатною універсальною цінністю з точки зору історії, мистецтва чи науки.

Визначні місця - твори людини або спільні витвори людини й природи, а також зони, включаючи археологічні визначні місця, що мають видатну універсальну цінність 3 точки зору історії, естетики, етнології чи антропології.

ЮНЕСКО та її партнерами вироблені наступні критерії відбору об'єктів для включення їх до Списку. 32005 р. критерії вказуються за новою схемою, встановленої в оновленій версії $[3,85] .31978$ р. список щодо критеріїв для об’єктів культурної спадщини налічував шість пунктів $[4,86]$. Потім для відновлення так званої рівноваги між різними континентами 3'явилися природні об'єкти і для них діяв список з чотирьох пунктів. I, нарешті, в 2005 р. всі ці критерії були зведені в єдине ціле і тепер кожен об'єкт світової спадщини має в своєму описі хоча б один з них.

На сьогодні діє єдиний перелік 310 критеріїв, визначених наскрізною нумерацією від i до х. При цьому критерії i-vi застосовуються для оцінки об'єктів культурної спадщини, критерії vii-x для оцінки об'єктів природної спадщини, для оцінки об’єктів змішаної (культурно-природної) спадщини можуть застосовуватися різні критерії [6, 105].

Для занесення до Списку необхідно, щоб об’єкт в повній мірі відповідав хоча б одному 3 нижченаведених критеріїв. Об'єкт, який номінується, повинен:

- бути творінням творчого генія людини;

- відображати істотний вплив взаємообміну загальнолюдськими цінностями в межах певного періоду часу чи певного культурного району світу на розвиток архітектури або технології, монументального мистецтва, містобудування чи планування ландшафтів;

- бути унікальним або, щонайменше, винятковим свідченням культурної традиції чи цивілізації, яка існує або зниклої;

- представляти видатний приклад типу будови, архітектурного чи технологічного ансамблю або ландшафту, що ілюструє важливий етап (етапи) в історії людства;

- представляти видатний приклад традиційного людського поселення чи землекористування, характерного для культури (культур) або взаємодії людини 3 навколишнім середовищем, особливо якщо вони руйнуються під впливом невідворотних чинників;

- бути прямо чи дотично пов'язаним з подіями або життєвими традиціями, ідеями чи віруваннями, творами літератури і мистецтва, що представляють видатне світове надбання;

- включати унікальні природні явища або території виняткової природної краси та естетичного значення;

- представляти видатні приклади основних етапів історії Землі, включаючи сліди стародавнього життя, серйозні геологічні процеси, які продовжують відбуватися в розвитку форм земної поверхні, істотні геоморфологічні чи фізико-географічні особливості рельєфу;

- представляти видатні приклади важливих, що протікають і в цей час, екологічних та біологічних процесів в еволюції й розвитку земних, прісноводих, прибережних і морських екосистем та співтовариств рослин й тварин;

- включати природні ареали великої важливості для збереження в них біологічного різноманіття, в тому числі ареали зникаючих видів, що представляють видатне світове надбання з точки зору науки і збереження природи. 
Крім того, об’єкти культурної спадщини для включення їх до Списку повинні пройти випробування, так званий «тест на справжність», який включає:

- справжність проекту;

- справжність матеріалу;

- справжність майстра виконання;

- справжність навколишнього оточення.

Обов'язкове проходження об'єктом-номінантом тесту на справжність має на меті не допускати включення копій або повністю реконструйованих будівель до Списку.

3'ясування того, відповідають чи ні об'єкти, що висуваються державами-сторонами Конвенції для включення до Списку, встановленим критеріям та умовам автентичності (цілісності), проводиться Міжнародною радою по пам'ятниках і визначних місцях (ICOMOS). Справжність матеріалу характеризує стан будівельного матеріалу, маючи на увазі максимальне збереження його початкових характеристик. Реалізація цього критерію передбачає збереження структури міської тканини та ії консервативну реабілітацію, а також заборону на переміщення історичних споруд [7, 127]. Відповідно до критерію автентичності задуму необхідне збереження матерії пам'ятника, слідів первісного використання будівельної технології. Справжність задуму означає збереження в пам'ятнику тих елементів, які свідчать про оригінальність художньої, архітектурної, конструктивної або функціональної ідеї, що становить основу пам'ятника та його цінність. Будь-який розвиток пам'ятника або ансамблю відповідно до цього критерію передбачає гармонізацію 3 початковим задумом. Справжність означає збереження контексту пам'ятника, бажано на момент створення $[8,16]$.

Процес номінації національних об'єктів до Списку включає кілька етапів:

- держава підписує Конвенцію, беручи на себе зобов'язання зберігати цю спадщину;

- держава-сторона Конвенції готує попередній список об'єктів культурної (і природної)

спадщини, розташованих на ії території, що мають визначну універсальну цінність;

- держава-сторона Конвенції відбирає об’єкти з попереднього списку для внесення їх до Списку;

- заповнену форму для включення об’єктів відсилають до Центру всесвітньої спадщини ЮНЕСКО;

- Центр всесвітньої спадщини ЮНЕСКО перевіряє правильність заповнення форми і направляє їі на оцінку в ICOMOS;

- експерти відвідують об'єкти та оцінюють їх збереження й управління;

- ICOMOS оцінює об'єкти-номінанти, використовуючи критерії культурної і природної спадщини;

- ICOMOS складає оціночний звіт;

- сім членів Бюро всесвітньої спадщини знайомляться з об'єктами-номінантами, з їх оцінками та дають рекомендації Міжурядового комітету з охорони всесвітньої культурної і природної спадщини (далі - Комітет);

- остаточне рішення приймається 21 членом Комітету з одним 3 наступних результатів: внести, відстрочити, відмовити.

Для всіх пропозицій стосовно включення об’єктів до Списку діє «Формат для пропозиції щодо включення культурних і природних багатств до Списку об'єктів всесвітньої спадщини ЮНЕСКО», розроблений Комітетом [9, 3].

Вся документація супроводжується належним чином підписаним дозволом, що дає ексклюзивне право для ЮНЕСКО безкоштовно ії відтворювати і використовувати. На практиці в пакеті документів подаються копії планів управління об'єктом, а також в стислому вигляді тлумачиться застосування національного законодавства держави, яка подає об'єкт-номінант. Бібліографія включає посилання на всі основні опубліковані джерела. Досьє на пропонований для включення до Списку об’єкт закріплюється підписом посадової особи, яка має повноваження підписувати його від імені держави. У країнах Союзу незалежних держав (СНД) досьє підписує Міністр культури.

Міжнародна угода вимагає, щоб об'єкти, включені до Списку, були відзначені емблемою та логотипом ЮНЕСКО, які розташовуються таким чином, щоб не порушувати естетичного 
враження від об'єкта. 3 метою впорядкування застосування норм Конвенції прийняті Основні принципи і правила використання емблеми Всесвітньої спадщини. Незважаючи на те, що емблема не згадується в Конвенції, Комітет з моменту затвердження емблеми в 1978 р. заохочує її використання для позначення об'єктів, що знаходяться під захистом Конвенції та включених до Списку $[10,67]$.

У зв'язку з включенням об'єкта до Списку на ньому розміщується меморіальна табличка, призначення якої сповішати населення конкретної держави та іноземних гостей про те, що об'єкт, який вони відвідали, має особливе значення, визнане міжнародним співтовариством, існування Конвенції або, як мінімум, про існування Концепції всесвітньої спадщини і Списку. Таблички встановлюються так, щоб вони були помітні для відвідувачів, не порушували при цьому зовнішнього вигляду об'єкта. На табличці поміщається емблема всесвітньої спадщини, в тексті зазначається виняткова цінність об'єкта, наводиться короткий опис його особливих характеристик.

Надання формального права на діяльність 3 використанням емблеми всесвітньої спадщини $є$ виключною прерогативою Комітету. Головним критерієм при прийнятті позитивних рішень про використання емблеми повинна бути освітня, наукова, культурна або художня цінність пропонованого об'єкту, пов'язана 3 принципами та цінностями всесвітньої спадщини. Тому рішення затвердити використання емблеми обумовлюється якістю і змістом об'єкта, на якому буде розміщено емблему, а не об'ємом очікуваного фінансового обороту [11, 62].

ЮНЕСКО забороняє розміщення емблеми на предметах, що мають вкрай малу освітню (просвітницьку) цінність або зовсім ії не мають. У випадках, коли використання емблеми не пов'язане чи лише дотично пов'язане з об'єктами всесвітньої спадщини (наприклад, при проведенні семінарів загального характеру або робочих семінарів 3 конкретних наукових проблем чи методів консерваціі), емблема може застосовуватися тільки в результаті недвозначно сформульованого дозволу. Забороняється використання емблеми транспортними агентствами, авіалініями або іншими організаціями та підприємствами, що діють переважно для отримання прибутку (виняток становлять особливі обставини і випадки, які не викликають сумніву в очевидній користі подібної пропозиції для всесвітньої спадщини загалом чи для будь-якого конкретного об'єкта зокрема).

3 огляду на викладене, вбачається, що на національному рівні повинні бути прийняті всі можливі заходи, щоб не допустити використання емблеми будь-якими особами в цілях, що суперечать ідеям всесвітньої спадщини. Для цього необхідно використовувати всі можливості внутрішнього законодавства, i, перш за все, закону про товарні знаки (знаки обслуговування) $[12,88]$.

Якщо країна не виконує взятих на себе відповідно до Конвенції зобов'язань, то можуть настати наступні несприятливі наслідки.

По-перше, іiі пам'ятки можуть бути виключені зі Списку. По-друге, про існування реальної загрози пам'ятці може бути направлена інформація в Комітет як від окремих осіб, так і від неурядових організацій. I, якщо попередження обгрунтоване, а проблема досить серйозна, то пам'ятка включається до Списку всесвітньої спадщини, що знаходиться в небезпеці.

На сьогодні до Списку всесвітньої спадщини, що знаходиться в небезпеці, внесені понад 50 об’єктів [13, 47].

До вказаного списку вносяться тільки ті об'єкти, яким загрожують конкретні та серйозні небезпеки, як, наприклад: ризик зникнення внаслідок прогресуючого руйнування або реалізації проектів проведення великих громадських (приватних) робіт; швидкий розвиток міст і туризму; руйнування в зв'язку із зникненням призначення або права власності на землю (покинута пам'ятка з яких-небудь причин); стихійне лихо та катаклізми; небезпека збройного конфлікту; великі пожежі; землетрус; зсуви; вулканічні виверження; зміни рівня вод, повені, припливи; значна втрата характеристик історичної автентичності; значна втрата культурної значущості.

Внесення об'єктів до зазначеного списку необхідно для того, щоб звернути на пам'ятки увагу світової спільноти і своєчасно вжити заходів для їх порятунку в разі загрози. Комітет 
може внести будь-який об'єкт до Списку всесвітньої спадщини, що знаходиться в небезпеці, якщо:

- об'єкт входить до Списку;

- об'єкту загрожує серйозна конкретна небезпека;

- для збереження об'єкта необхідне проведення серйозних заходів;

- щодо об’єкта вимагалось сприяння в рамках Конвенції.

У практичній діяльності Комітет дотримується позиції, що в певних випадках найбільш ефективним проявом сприяння може бути заклопотаність з боку Комітету і що подібне сприяння може запитуватися будь-яким членом Комітету.

У червні 2014 р. Комітет ухвалив рішення про занесення трьох об'єктів до Списку, що знаходиться в небезпеці. Такий захід допоможе надати міжнародну підтримку їх збереженню. У цьому числі Мисливський резерват Селус (Об'єднана Республіка Танзанія), Гірничозаводське місто Потосі (Болівія), Культурний ландшафт у південній частині Єрусалиму і селі Баттір (Держава Палестина). Із вказаного списку був виключений один об’єкт (Руїни Кілва-Кісівані і Сонг-Мнарі (Об'єднана Республіка Танзанія)) з урахуванням поліпшення стану його збереження. Цей об'єкт був включений до зазначеного списку в 2004 році у зв'язку з погіршенням його стану і руйнуванням, що призвели до втрати історичних та археологічних споруд, за які об'єкт був включений до Списку $[13,47]$.

Висновки. Необхідно зазначити, що включення пам'ятки до Списку означає, що вона стає об'єктом особливого правового захисту. Статус об'єкта світової спадщини дає певні переваги:

- створюються додаткові гарантії збереження і цілісності унікальних комплексів, підвищується привабливість територій;

- відбувається популяризація включених до Списку об'єктів;

- забезпечується пріоритетність у залученні фінансових коштів для підтримки об' єктів всесвітньої культурної і природної спадщини, в першу чергу, з Фонду всесвітньої спадщини, інвестицій для розвитку туристичного бізнесу $[14,145]$.

Таким чином, бачимо, що сьогодні у світі відпрацьований досить дієвий механізм зі збереження культурної спадщини. Велика роль, безумовно, належить міжнародним пам'яткоохоронним організаціям, проте основна робота щодо охорони пам'яток належить все-таки національним органам охорони культурної спадщини конкретних держав, що ми бачимо на прикладі Республіки Литва. Тому реальний захист ізбереження культурної спадщини розпочинається з усвідомлення людей, народів і суспільства того факту, що на території їхньої країни розташовані ті чи інші пам'ятки, які необхідно вивчати, обліковувати, охороняти i зберігати як частину історії та культури минулого для прийдешніх поколінь.

\section{Список використаної літератури}

1. Акуленко В. I. Міжнародне право охорони культурних цінностей та його імплементація у внутрішньому праві України: монографія. - К. : ТОВ «ВО «Юстініан», 2013. - 616 с.

2. Богуславский М. М. Культурные ценности в международном обороте: правовые аспекты. Москва: Видавництво «Норма», 2012. - 425 с.

3. Галенская Л. Н. Музы и право: правовые. вопросы международного сотрудничества в. области культуры / Л. Н. Галенская. - Ленинград: Изд-во ЛГУ, 1987. - 220 с.

4. Glemža J. R. Nekilnojamojo kultkros paveldo apsauga ir tvarkymas. - Vilnius: Vilniaus dails akad. leidykla, $-306 \mathrm{p}$.

5. Конвенція про охорону всесвітньої культурної і природної спадщини від 16.11.1972. 95 с. URL: http://www.rada.gov.ua.

6. Культурна спадщина людства: збереження та використання: навч. посіб. / В. Акуленко та ін. Львів : Фенікс, 2002. - 160 с.

7. Максаковский Н. В., Крогиус В. Р., Буторин А. А. Проблемы управления всемирным наследием: российский опыт в мировом контексте // Наследие и современность: информационный сборник. - Вип. 17. - Москва: 2010. - 198 с.

8. Максимов В. В. Правова охорона культурних цінностей у Конвенціях ЮНЕСКО: автореф. дис. канд. юрид. наук / Інститут держави і права ім. В.М.Корецького НАН України. - К., 1997. $-20 \mathrm{c}$. 
9. Мартиненко И. Е. Беларусь у сусветнай культурнай спадчыне. Беларусь і сучасная Еўропа: палітыка, эканоміка, культура; матэрыялы навуковых семінараў. - Мінск: Падручнікі і дапаможнікі, 2010 - $216 \mathrm{c}$.

10. Мельничук O. I. Статус Всесвітньої культурної та природної спадщини людства в міжнародному праві: дис. канд. юрид. наук: - К. : Інститут держави і права ім. В.М. Корецького НАН України, 2006. - 258 с.

11. Павлова Л. В. Статус всесвітньої культурної спадщини в міжнародному праві // Журн. міжнар. права і міжнар. відносин. - 2007 - №4 - 176 с.

12. Потапова Н. А. Международно-правовые проблемы охраны культурных ценностей и законодательство Российской Федерации: дис. канд. юрид. наук. - Москва: РУДН. - 195 с.

13. Утко Е. В., Шумихина О. В. Сокровища человечества. Все 962 памятника Всемирного наследия ЮНЕСКО. - Москва: Ексмо, - 208 с.

14. Фазлуллин С. М. Подводные парки как инструмент сохранения объектов подводного культурного наследия. Юридические и методические вопросы изучения и сохранения подводного культурного наследия: Сборник статей. - Москва, Рыбинск: ВАТ «Рыбинский дом печати», 2012. -235 с.

\section{References}

1. Akulenko V. I. (2013). International law for the protection of cultural property and its implementation in the domestic law of Ukraine: a monograph. Kyiv: LLC Justinian, 616 p. (in Ukr.).

2. Boguslavsky M. M. (2012) Cultural values in the international turnover: legal aspects. Moscow: Norm Publishing House, 425 p. (in Rus.).

3. Galenskaya L. N. (1987) Muses and Law. Leningrad, 188 p. (in Rus.).

4. Glemža J. R. Nekilnojamojo kultkros paveldo apsauga ir tvarkymas. Vilnius: Vilniaus dails akad. leidykla, 306 p. (in Ltu.).

5. Convention for the Protection of the World Cultural and Natural Heritage of 16.11.1972. 95 p. URL: http://www.rada.gov.ua. (in Ukr.).

6. Akulenko, V.I. et al. (2002). Cultural heritage of mankind: Preservation and use: a textbook. Lviv, 160 (in Ukr.)

7. Maksakovsky N. V., Krogius V. R., Butorin A. A. (2010) Problems of World Heritage Management: Russian Experience in the World Context. Heritage and Modernity: An Information Collection. Issue 17. Moscow. 198 p. (in Rus.).

8. Maksimov V. V. Legal protection of cultural property in the UNESCO Conventions: author. diss. cand. lawyer. Sciences: Kiyv, 187 p. (in Ukr.).

9. Martynenko I. E. Belarus in the World Cultural Heritage. Belarus and modern Europe: politics, economics, culture; materials of scientific seminars. Minsk: Textbooks and manuals, 2010, 216 p. (in Blr.).

10. Melnychuk O. I. The status of the World cultural and natural heritage of mankind in international law: diss. cand. lawyer. Sciences: Kiyv, 258 p. (in Ukr.).

11. Pavlova L. V. (2007) The status of the world cultural heritage in international law. Journal. international. law and intern. relations. 4, 176 p. (in Ukr.).

12. Potapova N. A. International legal problems of protection of cultural values and legislation of the Russian Federation: diss. cand. lawyer. Sciences. Moscow: RUDN, 195 p. (in Rus.).

13. Utko E. V., Shumikhina O. V. Treasures of humanity. All 962 UNESCO World Heritage Sites. Moscow: Exmo, 208 p. (in Rus.).

14. Fazlullin S. M. (2012). Underwater parks as a tool for conservation of underwater cultural heritage. Legal and methodological issues of studying and preserving underwater cultural heritage: Collection of articles. Moscow, Rybinsk: OJSC «Rybinsk Printing House», 2012, 235 p. (in Rus.).

KHARKOVENKO Roman, Candidate of Historical Sciences, Chief Specialist of the Ministry of

Culture and Information Policy of Ukraine,

e-mail:kredo3@ukr.net

\section{THE INTERNATIONAL ASPECT OF THE PROTECTION OF MONUMENTS OF THE CULTURAL HERITAGE OF THE REPUBLIC OF LITHUANIA}

Abstract. Introduction. The article examines and analyzes the international features of the protection of monuments of the cultural heritage of the Republic of Lithuania. 
Formulation of the problem. Every country in the world strives to protect and preserve its cultural heritage as effectively as possible. In the legislation of the vast majority of countries of the world, cultural heritage monuments are divided into three categories: local, national and international (global, world) significance (UNESCO monuments). The latter are inscribed on the UNESCO World Heritage List by the relevant decision of the said international organization.

There are as many countries in the world as there are practices for the protection of their own cultural heritage, its preservation, use and promotion, as well as cooperation with UNESCO in this area. In our opinion, the experience of such a small country as the Republic of Lithuania, which is so small in territory but quite conscious and responsible in the field of monument protection, is very interesting.

Goal. To analyze the international features in the field of protection of cultural heritage monuments of the Republic of Lithuania.

The research methodology is based on a system of theoretical principles (systematics, historicism, objectivity, etc.), logical methods (analysis and synthesis, induction and deduction, analogy, hypothesis, etc.) and specific research tools that provided an opportunity to highlight the international features in the field of cultural heritage protection of the Republic of Lithuania.

The main results of the research are the study, analysis, generalization and systematization of the bases of the national monument protection legislation of the Republic of Lithuania, as well as the consideration of Lithuanian cultural heritage monuments in the context of world cultural heritage.

The scientific novelty of the research results of the article is the analysis of the international legal norms of the United Nations and UNESCO on the protection of cultural heritage and compliance of the national legislation of the Republic of Lithuania with these norms.

Conclusions and specific suggestions of the author. At present, the world has developed a very effective mechanism for preserving cultural heritage. Of course, international monument protection organizations play an important role, but the main work on the protection of monuments still belongs to the national bodies for the cultural heritage protection of specific states, as we can see in the example of the Republic of Lithuania. Therefore, the real protection and preservation of cultural heritage begins with the awareness of people, nations, and society of the fact that in their country there are those monuments that need to be studied, accounted for, protected and preserved as a part of history and culture of the past for future generations.

Key words: protection of cultural heritage, object of cultural heritage, monument, UNESCO World Heritage List, Intergovernmental Committee for the Protection of World Cultural and Natural Heritage, Convention on the Protection of Cultural Heritage.

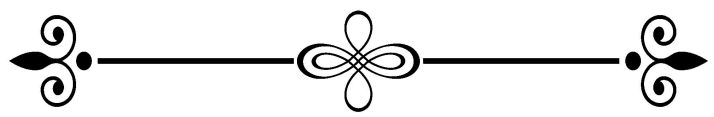

